\title{
ANALISIS PENGELOLAAN MODAL KERJA DAN AKTIVA TETAP TERHADAP KEMAMPULABAAN
}

\author{
Dita Andita Oftayani dan Yoyon Supriadi \\ STIE KESATUAN
}

\begin{abstract}
Every business has its own different goals, but in generally the success of the business is the main goals. One of the criteria to achieve the business succes is efficiency, it is shown when a company has a high profitability. The effective and efficient working capital and fixed assets management influence the level of profitability achievement in a company.
\end{abstract}

The purpose of this research is to know the effect of capital to profitability, fixed capital to profitability, and the management of working capital and fixed capital to profitability in PT. Kimia Farma Tbk dan PT. Kalbe Farma Tbk. to know the effect of that three variables.

And to test the significance of the effect of working capital (NWCTO) and Fixed Capital (FATO) to profitability (NPM) in both companies, the author analyzed and measured the relationship and influence between variables using regression coefficients, correlation coefficients ( $r$ ) and coefficient determination ( $r$ square). Based on the results of this study concluded that partial testing shows that in

PT. Kimia Farma Working Capital Management (NWCTO) has a significant influence to Fixed Capital (FATO), and Fixed Capital (FATO) has a significant impact on profitability (NPM). Simultaneous testing shows that working capital (NWCTO) and Fixed Capital (FATO) has a significant impact to profitability (NPM). Meanwhile, partial testing shows that in PT. Kalbe Farma Tbk. Working Capital Management (NWCTO) does not have a significant effect to Fixed Capital (FATO) and for Fixed Capital (FATO) does not have a significant impact on profitability (NPM). ). Simultaneous testing shows that working capital (NWCTO) and Fixed Capital (FATO) does not have a significant impact to profitability (NPM).

Key word :working capital management, fixed capital, profitability.

\section{PENDAHULUAN}

Seiring dengan pertumbuhan ekonomi pada era globalisasi sekarang ini meningkatkan persaingan usaha yang lebih ketat untuk mendapatkan tujuan perusahaan masing-masing dalam memaksimalkan keuntungannya, menghadapi persaingan dunia bisnis ini perusahaan dituntut untuk lebih efektif dan efisien dengan melakukan pengelolaan sumber daya yang ada pada perusahaan untuk mengetahui seberapa jauh perkembangan yang dihasilkan oleh perusahaan. Di era globalisasi saat ini jarak dan waktu sudah tidak menjadi masalah lagi. Disamping itu kemajuan teknologi dan ilmu pengetahuan yang sangat berkembang saat ini membuat berbagai negara berlombalomba untuk membuat inovasi terbaru di berbagai bidang. Pada dasarnya globalisasi ini memberikan berbagai dampak terhadap kelangsungan hidup perusahaan. Dilihat dari dampak positif aspek kreatifitas dengan semakin terbukanya pasar untuk produk-produk ekspor, hal ini tentu saja bisa membuat meningkatnya kualitas dan kuantitas produksi dengan cara membuat produk berkualitas tinggi. Hal ini disebabkan karena adanya dorongan untuk tetap bertahan ditengah persaingan global saat kini. Namun dampak positif tersebut bisa cenderung berbalik arah menjadi negatif bila perusahaan tidak 
mampu menciptakan produk berkualitas dengan harga yang kompetitif. Kondisi perekonomian Indonesia saat ini mulai mengalami penurunan dibandingkan tahun lalu, dengan persentase pertumbuhan ekonominya sebesar $6,5 \%$ merupakan yang tertinggi di ASEAN sementara laju inflasi 3,79\% menjadi yang terendah di Asia Pasifik. Peningkatan tersebut salah satunya disebabkan oleh peningkatan jumlah produk domestik bruto (PDB) sebagai faktor utama kinerja perekonomian indonesia. Salah satu faktor penurunan pertumbuhan ekonomi Indonesia dikarenakan penurunan ekspor barang terlebih adanya larangan ekspor atas beberapa logam antara lain nikel dan bauksit, ditambah pola hidup masyarakat Indonesia yang cenderung konsumtif yang gemar membeli produk impor semakin membuat neraca perdagangan Indonesia semakin minus. Pelarangan ekspor atas nikel dan bauksit menyumbang defisit sebesar $0,2 \%$. Di tengah faktor penurunan ekonomi Indonesia yang telah dijelaskan sebelumnya pada awal-awal tahun 2014 mengharapkan diakhir tahun ini perekonomian Indonesia akan membaik. Setidaknya hal tersebut tertolong oleh diselenggarakannya Pemilu 2014. Pemilu bisa menjadi dampak positif bagi konsumsi dalam negeri, produktivitas industri, tenaga kerja, serta membawa harapan baru bagi investor untuk kembali menanamkan modalnya di Indonesia.

Adanya era globalisasi juga berpengaruh kepada perekonomian Indonesia. AFTA dibentuk pada waktu Konperensi Tingkat Tinggi (KTT) ASEAN ke IV di Singapura tahun 1992. ASEAN Free Trade Area (AFTA) merupakan wujud dari kesepakatan dari negaranegara ASEAN untuk membentuk suatu kawasan bebas perdagangan dalam rangka meningkatkan daya saing ekonomi kawasan regional ASEAN dengan menjadikan ASEAN sebagai basis dunia akan dicapai dalam waktu 15 tahun (1993-2008), kemudian dipercepat menjadi tahun 2003, dan terakhir dipercepat lagi menjadi tahun 2008 produksi dunia serta menciptakan pasar regional bagi 500 juta penduduknya.

Dalam beberapa tahun terakhir ini kondisi perusahaan indonesia berhasil go internasional. Ukuran penjualan dan jumlah keuntungannya pun mulai menyaingi sejumlah perusahaan-perusahaan besar. Bahkan dari beberapa perusahaan yang termasuk dalam kategori 2000 perusahaan paling untung sedunia beberapa perusahaan indonesia mandapatkan keuntungan mencapai triliunan rupiah. Pencapaian itu didapatkan karena perusahaan- perusahaan di indonesia telah mampu menaikan kinerja perusahaan dan telah membuktikan bahwa walau Indonesia berada di tengah-tengah kondisi krisis global, perusahaan Indonesia masih mampu terus bertumbuh dan maju. Dalam kondisi perusahaan seperti ini perusahaan indonesia mampu bersaing dengan perusahaan perusahaan dari luar ( ASEAN ).

Pada umumnya setiap perusahaan didirikan dengan tujuan untuk memperoleh laba atas usaha yang didirikannya dan menjaga kelangsungan hidupnya perusahaan tersebut. Salah satu usaha yang digunakan oleh perusahan dalam usahanya adalah untuk menjaga kelangsungan hidupnya adalah dengan cara ekspansi usaha dan membutuhkan tambahan modal. Karena kebutuhan modal untuk keperluan ekspansi berangsur-angsur semakin membesar karena sifat ekspansi perusahaan yang dilakukan secara lambat dan berangsur-angsur. Pada tingkat ekspansi ini perusahaan membutuhkan modal kerja, karena perusahaan bekerja dengan kapasitas produksi yang tersedia. Modal kerja atau aktiva (kekayaan) diperlukan untuk melakukan kegiatan pembiayaan sehari-hari perusahaan dan selalu berputar. Melihat kondisi perekonomian Indonesia yang mengalami penurunan dibandingkan tahun lalu perusahaan harus mampu survive (hidup terus), haruslah berusaha semaksimal mungkin dan perlu adanya suatu pengembangan perusahaan. seorang manajer keuangan harus mampu dan tanggap untuk melihat perubahan-perubahan yang terjadi diperusahaan terutama yang menyangkut pengelolaan modal kerja yang dimulai dari perencanaan, penyusunan, pelaksanaan, dan pengawasan modal kerja itu sendiri. Mengingat masalah penurunan ekonomi salah satu yang dapat membantu adalah dengan memperhatikan masalah modal kerja. Pengelolaan modal kerja akan sangat menentukan posisi keuangan perusahaan jika adanya keseimbangan dalam hal penyediaan dan penggunaan modal kerja tersebut. Dan agar modal kerja bisa menjadi seimbang tidak kekurangan dan tidak kelebihan karena jumlah modal kerja yang terlalu besar akan berakibat sebagian dana yang tidak produktif, hal ini akan merugikan 
perusahaan karna kesempatan untuk memperoleh laba akan menjadi sia-sia, terlebih lagi apabila sampai terjadi kekurangan modal kerja, maka suatu perusahaan tidak akan dapat membiayai pengeluaran sehari-harinya. Misalkan untuk pembelian bahan mentah, membayar upah buruh, gaji pegawai dan lain sebagainya. Dengan pengelolaan modal kerja yang baik sebuah perusahaan dapat mencapai tujuannya. Oleh karena itu suatu perusahaan harus mengelola modal kerjanya dengan baik.

Modal kerja sangat diperlukan agar perusahaan selalu dapat menjalankan aktivitas dan efisiensinya dalam penggunaan modal kerja yang memegang peranan penting yaitu sebagai pengukur terhadap keberhasilan perusahaan. Suatu perusahaan dapat dikatakan sukses keuangannya apabila perusahaan tersebut selama menjalankan fungsi operasionalnya tidak menghadapi gangguan-gangguan keuangan, karena adanya antara uang yang masuk (pendapatan) dengan uang yang keluar (pengeluaran). Modal kerja memiliki peranan yang penting dalam kegiatan operasional perusahaan karena dengan tersedianya modal kerja yang cukup dapat membantu perusahaan untuk melancarkan kegiatan operasionalnya sehingga tujuan utama perusahaan tercapai dan dapat terus meningkat. Implementasi penggunaan modal kerja dapat dilihat dari penggunaan dan pengalokasian modal kerja tersebut. Pengelolaan modal yang efektif dan efisien akan meningkatkan laba perusahaan. Karena semakin tinggi modal kerja dan semakin tinggi perputaran modal kerja maka akan semakin tinggi pula laba yang diperoleh.

Setiap perusahaan yang didirikan tentu bertujuan untuk memperoleh laba atau keuntungan yang dapat dipergunakan untuk kemakmuran pemilik perusahaan atau pemegang saham. Sebuah perusahaan mempunyai harta (aktiva) untuk mendukung kegiatan usahanya dan mendapatkan keuntungan tersebut perusahaan melakukan modal kerja dan memperhatikan Aktiva tetap atau disebut juga sebagai aktiva tetap agar perusahaan tersebut bisa mencapai kemampulabaan.

Setiap perusahaan menggunakan berbagai macam aktiva tetap dalam melaksanakan kegiatan operasionalnya dan mempunyai masa manfaat lebih dari satu tahun seperti peralatan, perabotan, alat-alat, mesin, bangunan dan tanah. Penggunaan aktiva tetap setiap perusahaan berbeda-beda satu sama lainnya, tergantung dari jenis kebutuhan yang digunakan oleh perusahaan tersebut. Perusahaan harus cermat dan harus berhati-hati dalam penggunaan sumber dana, agar tidak menimbulkan kerugian yang dapat berakibat pada resiko kebangkrutan. Hal ini dapat dihindari dengan cara pengalokasian modal kerja perusahaan dan terus meningkatkan laba perusahaan. Dalam kegiatan yang dilakukan oleh perusahaan, proses perolehan aktiva tetap ini tentu memerlukan pertimbangan-pertimbangan bagi pihak perusahaan, karena kesalahan dalam mempertimbangkan cara memperoleh aktiva tetap ini akan mempengaruhi kegiatan operasional perusahaan, terutama dari segi dana. Untuk itu diperlukan sebuah perencanaan yang tepat, mengenai kebijakan apa yang perlu diambil untuk memperoleh aktiva tetap. Bisa diperoleh dengan berbagai cara, dimana masing-masing cara perolehan tersebut mempengaruhi besar kecilnya harga perolehan.

Penciptaan nilai perusahaan dimulai dari aktivitas setiap bagian perusahaan yang dilakukan secara berdayaguna dan berhasil guna (efektif dan efisien). Indikator terakhir dalam perusahaan akan nampak pada kemampulabaan perusahaan menciptakan laba dalam bisnis yang dijalankan. Kemampulabaan yang tinggi akan mempertinggi perusahaan. Sebaliknya kemampulabaan yang rendah sangat rentan atau sensitif terhadap perubahan harga baik secara umum maupun secara dalam persaingan.

Kemampulabaan adalah kemampuan menghasilkan laba tentang suatu pekerjaan. Setiap usaha mempunyai tujuan yang berbeda, namun pada umumnya keberhasilan usaha selalu menjadi tujuan utamanya. Salah satu kriteria untuk mencapai keberhasilan usaha adalah dengan efisiensi. Yaitu apabila sudah tercapai tingkat kemampulabaan (profitabilitas) yang tinggi.

Pengelolaan modal kerja yang efektif dan efisien serta aktiva tetap yang baik sangat berpengaruh terhadap pencapaian tingkat kemampulabaan yang tinggi pada suatu 
perusahaan, maka dari itu penulis tertarik memilih judul "Analisis Pengelolaan Modal Kerja dan Modal tetap terhadap kemampulabaan"

\section{Identifikasi Masalah}

Berdasarkan latar belakang yang telah di uraikan di atas, penulis akan mencoba menjabarkan identifikasi masalah sebagai berikut :

1. Bagaimana pengelolaan modal kerja dan Aktiva Tetap terhadap Kemampulabaan perusahaan selama periode penelitian pada PT. Kimia Farma Tbk dan PT. Kalbe Farma Tbk?

2. Bagaimana Pengaruh pengelolaan modal kerja dan aktiva tetap terhadap kemampulabaan perusahaan baik secara parsil dan simultan?

\section{Maksud dan Tujuan Penelitian}

Maksud dari penelitian ini adalah untuk memperoleh data dan informasi yang lengkap agar dapat dijadikan kajian dalam penulisan skripsi. Adapun tujuan penelitian adalah sebagai berikut:

1. Untuk mengetahui pengelolaan modal kerja dan aktiva tetap terhadap kemampulabaan perusahaan selama periode penelitian pada PT. Kimia Farma Tbk dan PT. Kalbe Farma Tbk.

2. Untuk mengetahui pengaruh pengelolaan modal kerja dan aktiva tetap terhadap kemampulabaan baik secara parsial dan simultan pada PT. Kimia Farma Tbk dan PT. Kalbe Farma Tbk.

\section{TINJAUAN PUSTAKA}

\section{Net Working Capital Turnover( NWCTO )}

Pengelolaan merupakan serangkaian usaha yang betujuan untuk menggali dan memanfaatkna segala potensi yang dimiliki secara efektif dan efisien guna mencapai tujuan tertentu yang telah direncanakan sebelumnya. Modal Kerja yang diteliti adalah modal kerja bersih. Keefektifan pengelolaan modal kerja tidak dilihat dari hasilnya tetapi dari perputarannya. Semakin besar angka perputarannya maka semakin baik pengelolaan modal kerjanya. Pengelolaan modal kerja dihitung dengan Turnover. Dalam Perhitunganpengelolaan modal kerja pendekatan yang digunakan adalah rasio Net Working Capital Turnover ( NWCTO ) yaitu rasio untuk mengukur aktivitas dan keefektivan modal kerja terhadap penjualan.

\section{Rasio Dalam Mengukur Modal Kerja}

Pada variabel pertama yaitu modal kerja ( Working Capital ) ada dua macam rasio untuk perputaran modal kerja dalam suatu perusahaan yaitu modal kerja kotor ( Working Capital Turnover ) didapat dari perhitungan penjualan dibagi dengan aktiva lancar dan yangkedua perputaran modal kerja bersih (Net Working Capital Turnover) didapat dari perhitungan penjualan dibagi dengan aktiva lancar dikurangi kewajiban lancar. Pada penelitian ini penullis menggunakan rasio Net Working capital Turnover karena penulis ingin mengetahui seberapa efektif perputaran modal kerja dilihat dari modal kerja bersihRasio ini menggambarkan tingkat perputaran modal kerja, semakin cepat perputaran modal kerja yang dihasilkan perusahaan maka akan semakin bagus.

Menurut Kasmir (2008:250) "Modal kerja merupakan modal yang digunakan untuk melakukan kegiatan operasi perusahaan. Modal kerja juga dapat diartikan sebagai investasi yang ditanamkan dalam aktiva lancar atau aktiva jangka pendek, seperti kas, surat-surat berharga, piutang, persediaan, dan aktiva lancar lainnya". 
Jadi dapat disimpulkan bahwa.Modal kerja merupakan investasi dalam harta jangka pendek atau investasi dalam harta lancar (current assets). Modal kerja dapat dikategorikan menjadi dua yaitu modal kerja kotor (gross working capital) dan modal kerja bersih adalah jumlah harta lancar dikurangi jumlah utang lancar (current liabilities). Manajemen modal kerja mengelola harta lancar dan utang lancar agar harta lancar selalu lebih besar daripada utang lancer, Rasio modal kerja dihitung dengan formula :

$$
\begin{aligned}
& \text { Net Working Capital Turn Over }=\frac{\text { Penjualan }}{\text { Modal Kerja Bersih }} \\
& \text { Modal Kerja Bersih= Aktiva Lancar }- \text { Hutang Lancar }
\end{aligned}
$$

\section{Fixed Asset Turnover( FATO )}

Aktiva dikategorikan menjadi aktiva berwujud dan tidak berwujud yang digunakan dalam operasi perusahaan dan tidak dimaksudkan untuk dijual dalam kegiatan normal perusahaan. Untuk menghitung aktiva tetap menggunakan pendekatan Fixed Asset Turnover ( FATO ) yaitu rasio untuk mengukur seberapa efektif perusahaan dalam memanfaatkan sumber aktiva tetapnya di dalam kegiatan operasional perusahaan.

Aktiva Tetap Menurut Jerry J. Weygandt (2007:566) yang di alih bahasakan oleh Ali Akbar Yulianto, Wasilah, dan Rangga Handika, mengemukakan pengertian aktiva tetap sebagai berikut: "Aset tetap (plant assets) adalah sumber daya yang memiliki tiga karakteristik: memiliki bentuk fisik, digunakan dalam kegiatan operasional, dan tidak untuk dijual ke konsumen."

Menurut Sugiri dalam buku Akuntansi Pengantar 2 (2009:137) sebagai berikut "Asset berwujud yang tujuan pemilikannya adalah untuk digunakan dalam produksi atau penyediaan barang atau jasa, untuk direntalkankepada pihak lain, atau tujuan administratif dan diharapkan untuk digunakan selama lebih dari satu periode".

Berdasarkan beberapa pengertian di atas dapat disimpulkan bahwa aktiva tetap merupakan investasi yang dilakukan oleh perusahaan dalam jangka panjang (lebih dari satu tahun) yang bertujuan untuk tidak dijual kembali melainkan untuk digunakan dalam kegiatan operasional perusahaan.

Aktiva tetap hanya ada satu rasio untuk mengukur perputaran Aktiva tetap dalam suatu perusahaan yaitu penjualan Aktiva tetap ( Fixed asset Turnover) didapat dari perhitungan penjualan dibagi dengan aktiva tetap. Pada penelitian ini penulis menggunakan rasio Fixed Asset Turnover karena penulis ingin mngetahui seberapa efektif perusahaan dalam memanfaatkan aktiva tetap yang dimiliki oleh perusahaan.

FATO dapat dihitung dengan menggunakan rumus :

$$
\text { Fixed Asset Turn Over }=\frac{\text { Penjualan }}{\text { Aktiva Tetap }}
$$

\section{Net Profit Margin ( NPM )}

Kemampulabaan (profitabilitas) adalah suatu ukuran dalam presentase yang digunakan untuk menilai sejauh mana perusahaan mampu menghasilkan laba pada tingkat yang dapat diterima. Angka profitabilitas dinyatakan antara lain dalam angka laba sebelum atau sesudah pajak, laba investasi, pendapatan per saham dan laba penjuala. Nilai profitabilitas menjadi norma ukuran bagi kesehatan perusahaan.

Rasio kemampulabaan (profitabilitas) menurut Brigham and Houston (2009:107), yaitu: "Sekelompok rasio yang menunjukkan gabungan efek-efek dari likuiditas, manajemen aktiva, dan utang pada hasil operasi. Rasio ini meliputi margin laba atas penjualan, rasio kemampuan dasar untuk menghasilkan laba, tingkat pengembalian atas total aktiva, dan tingkat pengembalian ekuitas saham biasa". 
Rasio kemampulabaan (profitabilitas) menurut Sutrisno (2009:222), yaitu: "Rasio untuk mengukur seberapa besar tingkat keuntungan yang dapat diperoleh oleh perusahaan".

Rasio kemampulabaan (Profitabilitas) menurut Fred Weston dan Thomas E. Copeland (2010:237), yaitu: "measuring the management effectiveness based on the return of sales and investment".

Berdasarkan beberapa pengertian diatas tersebut maka rasio dapat diambil kesimpulan rasio profitabilitas adalah rasio untuk mengukur seberapa besar sebuah perusahaan mampu menghasilkan laba dengan menggunakan semua faktor perusahaan yang ada di dalamnya untuk menghasilkan laba yang maksimal.

\section{Kegunaan dan Manfaat dari Net Profit Margin ( NPM )}

Profitabilitas yang digunakan sebagai kriteria penilaian hasil operasi perusahaan mempunyai manfaat yang sangat penting dan dapat dipakai sebgai berikut:

1. Analisis kemampulabaan menghasilkan laba ditunjukan untuk mendeteksi penyebab timbulnya laba atau rugi yang dihasilkan oleh suatu objek informasi dalam periode akuntansi tertentu.

2. Profitabilitas dapat dimanfaatkan untuk menggambarkan kriteria yang sangat diperlukan dalam menilai sukses suatu perusahan dalm hal kapabilitas dan motivasi dari manajemen.

3. Profitabilitas merupakan suatu alat untuk membuat proyeksi laba perusahaan karena menggamberkan korelasi antra laba dan jumlah modal yang ditanamkan.

4. Profitabilitas merupakan suatu alat pengendalian bagi manajemen, profitabilitas dapat dimanfaatkan oleh pihak intern untuk menyusun target, budget, koordinasi, evaluasi hasil pelaksanaan operasi perusahaan dan dasar pengambilan keputusan.

\section{PerhitunganNet Profit Margin ( NPM )}

Rumus yang digunakan untuk mengukurNet Profit Margin ( NPM )adalah sebagai berikut:

$$
\text { Net profit Margin }=\frac{\text { Laba Bersih Setelah Pajak }}{\text { Penjualan Bersih }} \times 100 \%
$$

\section{Kerangka Pemikiran Konseptual}

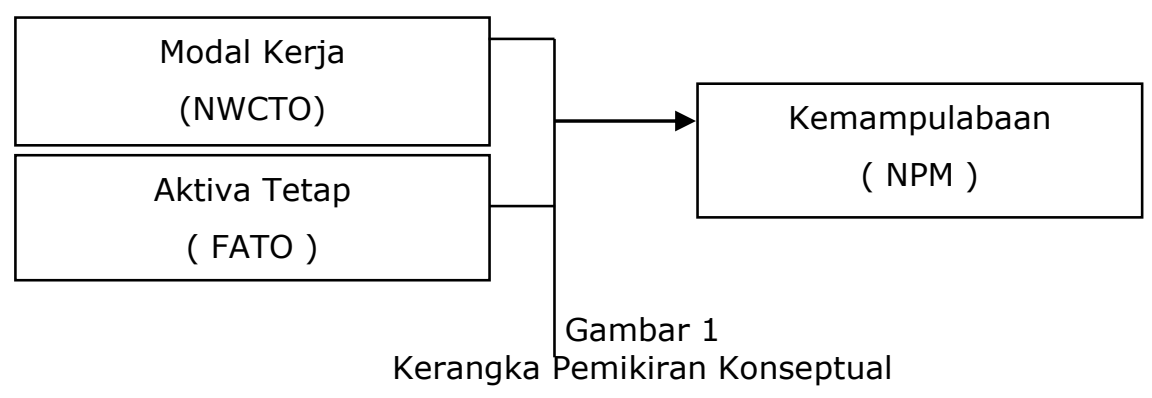




\section{Hipotesis Penelitian}

Pada penelitian ini dilakukan pengujian hipotesis atau signifikansi dari identifikasi masalah baik secara parsial dengan uji t maupun simultan dengan uji F. Adapun hipotesis yang penulis buat adalah sebagai berikut :

1. Secara Parsial

$\mathrm{H}_{01} \quad$ : Modal Kerja berpengaruh signifikan terhadap kemampulabaan Perusahaan.

$\mathrm{H}_{\mathrm{a} 1}$ : Modal Kerja tidak berpengaruh signifikan terhadap kemampulabaan Perusahaan.

$\mathrm{H}_{02} \quad$ :Aktiva tetap berpengaruh signifikan terhadap kemampulabaan Perusahaan.

$\mathrm{H}_{\mathrm{a} 2}$ : Aktiva tetap tidak berpengaruh signifikan terhadap kemampulabaan Perusahaan.

2. Secara Simultan

$\mathrm{H}_{03} \quad$ : Terdapat pengaruh antara modal kerja dan aktiva tetap secara bersamasama terhadap kemampulabaan Perusahaan.

$\mathrm{H}_{\mathrm{a} 3} \quad$ : Tidak terdapat pengaruh antara modal kerja dan aktiva tetap secara bersama-sama terhadap kemampulabaan Perusahaan.

\section{METODOLOGI PENELITIAN}

Penelitian ini dilakukan dengan metode komparatif, metode deskriptif, dan metode analisis rasio. Operasionalisasinya sebagai berikut :

\begin{tabular}{|l|r|c|}
\hline $\begin{array}{l}\text { Variabel / Sub } \\
\text { Variabel }\end{array}$ & Skala Ukuran \\
\hline Modal Kerja (X1) & NWCTO & Rasio \\
\hline (Net Working Capital Turn Over) & RATO & Rasio \\
\hline $\begin{array}{l}\text { Kemampulabaan } \\
\text { (Y1) }\end{array}$ & (Fixed Asset Turn Over) & Rasio \\
\hline
\end{tabular}

Cara pengumpulan data yang dilakukan penulis untuk mengumpulkan data-data yang diperlukan adalah melalui studi kepustakaan (library research) dengan membaca dan mempelajari bahan-bahan literature yang berhubungan dengan topic penelitian yang dibahas.

Metode analisis yang digunakan penulis dalam menganalisis data-data tersebut menggunakan analisis rasio, analisis koefisien, analisis regresi dan uji signifikansi melalui uji-t dan uji-f.

HASIL DAN PEMBAHASAN

Analisis Pengaruh Modal Kerja terhadap Kemampulabaan PT.Kimia Farma Tbk . Model Summary 


\begin{tabular}{|l|l|l|l|l|}
\hline Model & $R$ & R Square & Adjusted R Square & Std. Error of the Estimate \\
\hline dimension01 & $, 516^{\mathrm{a}}, 266$ &, 225 &, 01187 \\
\hline
\end{tabular}

a. Predictors: (Constant), NWCTO

b. Dependent Variable: NPM

Berdasarkan hasil perhitungan diatas diperoleh nilai korelasi $(R)$ sebesar 0,516 atau $51,6 \%$. Nilai R 0.516 menjelaskan bahwa korelasi antara variabel independen Modal kerja ( net working capital turnover ) terhadap variabel dependen Kemampulabaan ( NPM ) 0.516 atau $51,6 \%$ yang mengandung arti bahwa hubungan antara kedua variabel tidak cukup erat. Selanjutnya dari tabel di atas juga diketahui nilai determinasi ( R Square ) sebesar 0.266 atau 26,6\% angka ini menjelaskan bahwa variabel Modal kerja ( net working capital turnover ) hanya memberikan kontribusi terhadap Kemampulabaan (NPM) sebesar $26,6 \%$ sedangkan sisanya sebesar $73.4 \%$ (1-26,6\%) merupakan kontribusi dari variabel lain yang tidak diteliti.

Coefficients $^{a}$

\begin{tabular}{|ll|l|l|l|l|l|}
\hline \multicolumn{2}{|l|}{ Model } & \multicolumn{2}{|l|}{ Unstandardized Coefficients } & $\begin{array}{l}\text { Standardized } \\
\text { Coefficients }\end{array}$ & & \multirow{2}{*}{} \\
\cline { 3 - 5 } & & $\mathrm{B}$ & Std. Error & Beta & $\mathrm{t}$ & Sig. \\
\hline 1 & (Constant) &, 025 &, 006 & & 4,106 &, 001 \\
& NWCTO &, 005 &, 002 &, 516 & 2,555 &, 020 \\
\hline
\end{tabular}

a. Dependent Variable: NPM

Berdasarkan data di atas, maka pengaruh antara modal kerja terhadap kemampulabaan pada PT. Kimia Farma Tbk dapat diketahui dalam persamaan regresi sebagai berikut :

$$
Y=0,025+0,005 X+\text { error }
$$

Dimana :

$\mathrm{Y}=$ kemampulabaan

$\mathrm{X}=$ modal kerja

Persamaan tersebut menunjukkan bahwa nilai konstanta (a) sebesar 0,025 yang berarti bahwa bila nilai Net working capital Turnover $=0$ maka kemampulabaan akan bertambah sebesar 0,025. Sementara itu nilai konstanta Net working capital Turnover sebesar 0,005 mengandung arti bahwa jika Net working capital Turnover sebesar satu satuan maka kemampulabaan akan bertambah sebesar 0,005.

Disamping itu berdasarkan tabel 4.2.1.2 di atas diperoleh tingkat signifikan hasil uji t dari variabel independen Modal Kerja ( Net working capital Turnover ) terhadap Kemampulabaan (NPM) diperoleh hasil bahwa $t$ hitung adalah 2,555 dan nilai signifikansinya 0,020 $<0,05$ maka berarti $t$ hitung $>\mathrm{t}$ tabel $(2,555>2,093)$ maka berarti Ho ditolak dan $\mathrm{H} 1$ diterima. Dengan demikian dapat disimpulkan bahwa Modal Kerja memiliki pengaruh yang signifikan terhadap kemampulabaan.

\section{Analisis Pengaruh Modal Kerja terhadap Kemampulabaan PT.Kalbe Farma Tbk}


Model Summaryb

\begin{tabular}{|l|l|l|l|l|}
\hline Model & $R$ & R Square & Adjusted R Square & Std. Error of the Estimate \\
\hline dimension01 &, $373^{\mathrm{a}}$ &, 139 &, 091 &, 00794 \\
\hline
\end{tabular}

a. Predictors: (Constant), NWCTO

b. Dependent Variable: NPM

Berdasarkan hasil perhitungan diatas diperoleh nilai korelasi (R) sebesar 0,373 atau $37,3 \%$. Nilai R 0.373 menjelaskan bahwa korelasi antara variabel independen Modal kerja (net working capital turnover) terhadap variabel dependen Kemampulabaan ( NPM ) 0.373 atau $37,3 \%$ yang mengandung arti bahwa hubungan antara kedua variabel rendah. Selanjutnya dari tabel di atas juga diketahui nilai determinasi ( $R$ Square) sebesar 0.139 atau $13,9 \%$ angka ini menjelaskan bahwa variabel Modal kerja ( net working capital turnover ) hanya memberikan kontribusi terhadap Kemampulabaan (NPM) sebesar 13,9\% sedangkan sisanya sebesar $86 ., \%(1-13,9 \%)$ merupakan kontribusi dari variabel lain yang tidak diteliti.

\section{Coefficients $^{\mathrm{a}}$}

\begin{tabular}{|c|c|c|c|c|c|c|}
\hline \multirow{2}{*}{\multicolumn{2}{|c|}{ Model }} & \multicolumn{2}{|c|}{ Unstandardized Coefficients } & \multirow{2}{*}{\begin{tabular}{|l}
$\begin{array}{l}\text { Standardized } \\
\text { Coefficients }\end{array}$ \\
Beta
\end{tabular}} & \multirow[b]{2}{*}{ t } & \multirow[b]{2}{*}{ Sig. } \\
\hline & & $B$ & Std. Error & & & \\
\hline \multirow[t]{2}{*}{1} & (Constant) & 135 &, 004 & & 31,764 &, 000 \\
\hline & NWCTO &,- 004 &, 002 &,- 373 & $-1,707$ &, 105 \\
\hline
\end{tabular}

a. Dependent Variable: NPM

Berdasarkan data di atas, maka pengaruh antara modal kerja terhadap kemampulabaan pada PT. Kimia Farma Tbk dapat diketahui dalam persamaan regresi sebagai berikut :

$Y=0,135+0,004 X+$ Error

Dimana :

$Y=$ kemampulabaan

$\mathrm{X}=$ modal kerja

Persamaan tersebut menunjukkan bahwa nilai konstanta (a) sebesar 0,135 yang berarti bahwa bila nilai Net working capital Turnover $=0$ maka kemampulabaan akan bertambah sebesar 0,135 . Sementara itu nilai konstanta Net working capital Turnover sebesar 0,004 mengandung arti bahwa jika Net working capital Turnover sebesar satu satuan maka kemampulabaan akan bertambah sebesar 0,004.

Disamping itu berdasarkan tabel di atas diperoleh tingkat signifikan hasil uji t dari variabel independen Modal Kerja ( Net working capital Turnover ) terhadap Kemampulabaan (NPM) diperoleh hasil bahwa $t$ hitung adalah $-1,707$ dan nilai signifikansinya 0,105 $>0,05$ maka berarti t hitung $<\mathrm{t}$ tabel $(-1,707<2,093)$ maka berarti Ho diterima dan $\mathrm{H} 1$ ditolak. Dengan demikian dapat disimpulkan bahwa Modal Kerja tidak memiliki pengaruh yang signifikan terhadap kemampulabaan.

\section{Analisis Pengaruh Aktiva Tetap terhadap Kemampulabaan PT.Kimia Farma Tbk.}


Model Summaryb

\begin{tabular}{|c|c|c|c|c|}
\hline Model & $\mathrm{R}$ & R Square & Adjusted R Square & Std. Error of the Estimate \\
\hline dimensiono 1 & $610^{\mathrm{a}}$ & 372 & 337 & 01098 \\
\hline
\end{tabular}

a. Predictors: (Constant), FATO

b. Dependent Variable: NPM

Berdasarkan hasil perhitungan diatas diperoleh nilai korelasi $(R)$ sebesar 0,610 atau $61 \%$. Nilai R 0.610 menjelaskan bahwa korelasi antara variabel independen Aktiva Tetap ( Fixed Asset turnover ) terhadap variabel dependen Kemampulabaan ( NPM ) 0.610 atau $61 \%$ yang mengandung arti bahwa hubungan antara kedua variabel kuat erat. Selanjutnya dari tabel di atas juga diketahui nilai determinasi ( $R$ Square) sebesar 0.372 atau 37,2\% angka ini menjelaskan bahwa variabel Aktiva Tetap ( Fixed Asset turnover ) hanya memberikan kontribusi terhadap Kemampulabaan (NPM) sebesar 37,2\% sedangkan sisanya sebesar $62.8 \%(1-37.2 \%)$ merupakan kontribusi dari variabel lain yang tidak diteliti.

Coefficients $^{\mathrm{a}}$

\begin{tabular}{|ll|l|l|l|l|l|}
\hline \multicolumn{2}{|l|}{ Model } & \multicolumn{2}{|l|}{ Unstandardized Coefficients } & $\begin{array}{l}\text { Standardized } \\
\text { Coefficients }\end{array}$ & & \multirow{2}{*}{} \\
\cline { 3 - 5 } & & $\mathrm{B}$ & Std. Error & Beta & $\mathrm{t}$ & Sig. \\
\hline 1 & (Constant) & 023 &, 005 & & 4,466 &, 000 \\
& FATO &, 004 &, 001 &, 610 & 3,262 &, 004 \\
\hline
\end{tabular}

a. Dependent Variable: NPM

Berdasarkan data di atas, maka pengaruh antara Aktiva tetap terhadapkemampulabaan pada PT. Kimia Farma Tbk dapat diketahui dalam persamaan regresi sebagai berikut :

$Y=0,023+0,004 X+$ error

Dimana :

$\mathrm{Y}=$ kemampulabaan

$X=$ Aktiva tetap

Persamaan tersebut menunjukkan bahwa nilai konstanta (a) sebesar 0,023 yang berarti bahwa bila nilai Fixed Asset turnover $=0$ maka kemampulabaan akan bertambah sebesar 0,023. Sementara itu nilai konstanta Fixed Asset turnover sebesar 0,004 mengandung arti bahwa jika Fixed Asset turnover sebesar satu satuan maka kemampulabaan akan bertambah sebesar 0,004.

Disamping itu berdasarkan tabel di atas diperoleh tingkat signifikan hasil uji t dari variabel independen Aktiva Tetap ( Fixed Asset turnover) terhadap Kemampulabaan (NPM) diperoleh hasil bahwa t hitung adalah 3,262 dan nilai signifikansinya 0,004 $<0,05$ maka berarti t hitung $>\mathrm{t}$ tabel $(3,262>2,093)$ maka berarti Ho ditolak dan H1 diterima. 
Dengan demikian dapat disimpulkan bahwa Aktiva tetap memiliki pengaruh yang signifikan terhadap kemampulabaan.

\section{Analisis Pengaruh Aktiva Tetap terhadap Kemampulabaan PT.Kalbe Farma Tbk.}

Model Summaryb

\begin{tabular}{|l|l|l|l|l|}
\hline Model & $R$ & R Square & Adjusted R Square & Std. Error of the Estimate \\
\hline dimension01 & ,069a &, 005 &,- 051 &, 00854 \\
\hline
\end{tabular}

a. Predictors: (Constant), FATO

b. Dependent Variable: NPM

Berdasarkan hasil perhitungan diatas diperoleh nilai korelasi ( $R$ ) sebesar 0,069 atau 6,9\%. Nilai R 0.069 menjelaskan bahwa korelasi antara variabel independen Aktiva Tetap ( Fixed Asset turnover ) terhadap variabel dependen Kemampulabaan ( NPM ) 0.069 atau $6,9 \%$ yang mengandung arti bahwa hubungan antara kedua variabel kuat. Selanjutnya dari tabel di atas juga diketahui nilai determinasi (R Square) sebesar 0.005 atau 0,5\% angka ini menjelaskan bahwa variabel Aktiva Tetap ( Fixed Asset turnover ) hanya memberikan kontribusi terhadap Kemampulabaan (NPM) sebesar 0,5\% sedangkan sisanya sebesar 99,5\% (1-0,5\%) merupakan kontribusi dari variabel lain yang tidak diteliti.

Coefficients ${ }^{\mathrm{a}}$

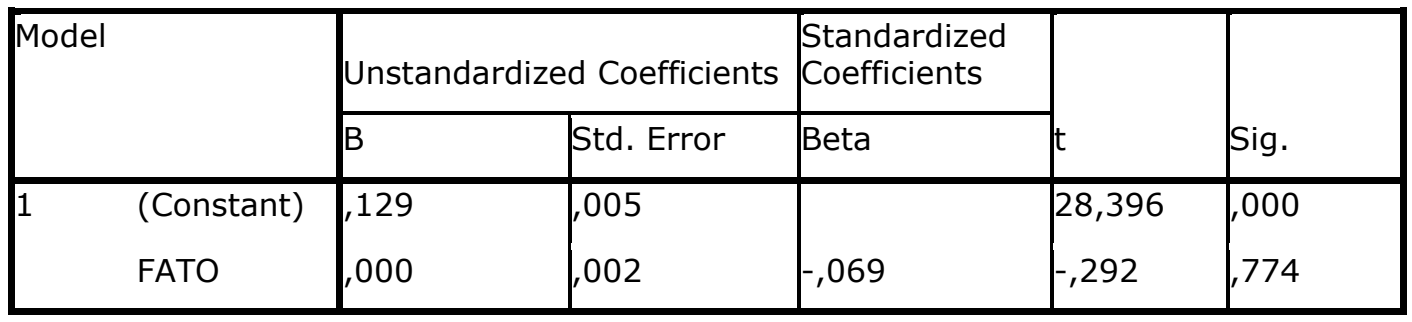

a. Dependent Variable: NPM

Berdasarkan data di atas, maka pengaruh antara Aktiva tetap terhadap kemampulabaan pada PT. Kimia Farma Tbk dapat diketahui dalam persamaan regresi sebagai berikut :

$Y=0,129+0,000 X+$ Error

Dimana :

$\mathrm{Y}=$ kemampulabaan

$\mathrm{X}=$ Aktiva tetap

Persamaan tersebut menunjukkan bahwa nilai konstanta (a) sebesar 0,129 yang berarti bahwa bila nilai Fixed Asset turnover $=0$ maka kemampulabaan akan bertambah sebesar 0,129. Sementara itu nilai konstanta Fixed Asset turnover sebesar 0,000 mengandung arti bahwa jika Fixed Asset turnover sebesar satu satuan maka kemampulabaan akan bertambah sebesar 0,000.

Disamping itu berdasarkan tabel di atas diperoleh tingkat signifikan hasil uji t dari variabel independen Aktiva Tetap ( Fixed Asset turnover ) terhadap Kemampulabaan (NPM) diperoleh hasil bahwa t hitung adalah -0,292 dan nilai signifikansinya 0,774 $>0,05$ maka berarti t hitung $>\mathrm{t}$ tabel $(-0,292>2,093)$ maka berarti Ho diterima dan H1 ditolak. 
Dengan demikian dapat disimpulkan bahwa Aktiva tetap tidak memiliki pengaruh yang signifikan terhadapkemampulabaan.

\section{Analisis Pengaruh Modal Kerja dan Aktiva Tetap terhadap Kemampulabaan PT.Kimia Farma Tbk.}

Model Summary

\begin{tabular}{|l|l|l|l|l|}
\hline Model & $R$ & R Square & Adjusted R Square & Std. Error of the Estimate \\
\hline dimension01 & $645^{\mathrm{a}}, 416$ &, 347 &, 01089 \\
\hline
\end{tabular}

a. Predictors: (Constant), FATO, NWCTO

b. Dependent Variable: NPM

Berdasarkan hasil perhitungan diatas diperoleh nilai korelasi $(R)$ sebesar 0,645 atau $64,5 \%$. Nilai R 0.645 menjelaskan bahwa korelasi antara variabel independen Modal Kerja ( Net Working Capital Turnover ) Aktiva Tetap ( Fixed Asset turnover) terhadap variabel dependen Kemampulabaan ( NPM ) 0.645 atau $64,5 \%$ yang mengandung arti bahwa hubungan antara kedua variabel kuat. Selanjutnya dari tabel di atas juga diketahui nilai determinasi ( $R$ Square) sebesar 0.416 atau $41,6 \%$ angka ini menjelaskan bahwa keragaman dari kemampulabaan ( NPM ) dapat dijelaskan oleh Modal kerja ( NWCTO ) dan Aktiva Tetap ( FATO ) sedangkan sisanya sebesar 58,4\% (1-41,6\%) merupakan kontribusi dari variabel lain yang tidak diteliti.

Coefficients $^{a}$

\begin{tabular}{|ll|l|l|l|l|l|}
\hline \multicolumn{2}{|l|l|l|}{} & \multicolumn{2}{|l|}{ Unstandardized Coefficients } & $\begin{array}{l}\text { Standardized } \\
\text { Coefficients }\end{array}$ & & \multirow{2}{*}{} \\
\cline { 3 - 5 } & & B & Std. Error & Beta & t & Sig. \\
\hline 1 & (Constant) &, 026 &, 006 & & 4,619 &, 000 \\
& NWCTO &,- 007 &, 006 &,- 692 & $-1,140$ &, 270 \\
& FATO &, 009 &, 004 & 1,269 & 2,089 &, 052 \\
\hline
\end{tabular}

a. Dependent Variable: NPM

Berdasarkan data di atas, maka pengaruh antara modal kerja dan Aktiva tetap terhadap kemampulabaan pada PT. Kimia Farma Tbk diperoleh hasil:

$Y=0,026-0,007_{x 1}+0,009_{\times 2}-$ Error

Persamaan tersebut menunjukkan bahwa nilai konstanta (a) sebesar 0,026 yang berarti bahwa bila nilai Net Working Capital Turnover dan Fixed Asset turnover $=0$ maka kemampulabaan akan berkurang sebesar 0,026. Sementara itu nilai konstanta Net Working Capital Turnover sebesar 0,007 mengandung arti bahwa jika Net Working Capital Turnover turun sebesar satu satuan dan variable lainnya konstan maka kemampulabaan akan turun sebesar 0,007. Nilai konsta FATO diperoleh sebesar 0,009 artinya jika FATO naik sebesar satu satuan dan variable lainnya konstan maka kemampulabaan akan meningkat sebesar 0,009. 


\begin{tabular}{|ll|l|l|l|l|l|}
\hline Model & & $\begin{array}{l}\text { Sum of } \\
\text { Squares }\end{array}$ & $\mathrm{df}$ & Mean Square & $\mathrm{F}$ & Sig. \\
\hline 1 & Regression & 001 & 2 &, 001 & 6,059 &, $010^{\mathrm{a}}$ \\
& $\begin{array}{l}\text { Residual } \\
\text { Total }\end{array}$ &, 002 & 17 &, 000 & & \\
& & & 19 & & & \\
\hline
\end{tabular}

a. Predictors: (Constant), FATO, NWCTO

b. Dependent Variable: NPM

Uji F ( Anova ) atau Uji koefisien regresi secara bersama - sama digunakan untuk mengetahui apakah variable independen Net Working Capital Turnover dan Fixed Aset Turnover secara bersama - sama tidak berpanguruh signifikan terhadap kemampulabaan. Berdasarkan hasil perhitungan seperti yang nampak pada tabel 4.2.5.3 diatas menunjukan bahwa $\mathrm{f}$ hitung $>\mathrm{f}$ tabel $(6,056>3591)$ dan tingkat signifikansi 0,010< 0,05 maka dapat dijelaskan bahwa variabel independen Net Working Capital Turnover dan Fixed Asset Turnover secara bersama - sama memiliki hubungan yang signifikan terhadap Kemampulabaan ( NPM ).

\section{Analisis Pengaruh Modal Kerja dan Aktiva Tetap terhadap Kemampulabaan PT.Kalbe Farma Tbk}

Model Summary

\begin{tabular}{|l|l|l|l|l|}
\hline Model & $R$ & $\begin{array}{l}\mathrm{R} \\
\text { Square }\end{array}$ & $\begin{array}{l}\text { Adjusted } \mathrm{R} \\
\text { Square }\end{array}$ & Std. Error of the Estimate \\
\hline dimension01 &, $382^{\mathrm{a}}$ &, 146 &, 046 &, 00814 \\
\hline
\end{tabular}

a. Predictors: (Constant), FATO, NWCTO

Berdasarkan hasil perhitungan diatas diperoleh nilai korelasi $(R)$ sebesar 0,382 atau 38,2\%. Nilai R 0.382 menjelaskan bahwa korelasi antara variabel independen Modal Kerja ( Net Working Capital Turnover ) Aktiva Tetap ( Fixed Asset turnover ) terhadap variabel dependen Kemampulabaan ( NPM ) 0.382 atau 38,2\% yang mengandung arti bahwa hubungan antara kedua variabel rendah. Selanjutnya dari tabel di atas juga diketahui nilai determinasi ( $R$ Square) sebesar 0.146 atau $14,6 \%$ angka ini menjelaskan bahwa kergaman dari kemampulabaan ( NPM ) dapat dijelaskan oleh Modal kerja ( NWCTO ) dan Aktiva Tetap ( FATO ) sedangkan sisanya sebesar 85,4\% (1-14,6\%) merupakan kontribusi dari variabel lain yang tidak diteliti.

\section{Coefficients $^{\mathrm{a}}$}

\begin{tabular}{|c|c|c|c|c|c|c|}
\hline \multirow{2}{*}{\multicolumn{2}{|c|}{ Model }} & \multicolumn{2}{|c|}{ Unstandardized Coefficients } & \multirow{2}{*}{\begin{tabular}{|l}
$\begin{array}{l}\text { Standardized } \\
\text { Coefficients }\end{array}$ \\
Beta
\end{tabular}} & \multirow[b]{2}{*}{$t$} & \multirow[b]{2}{*}{ Sig. } \\
\hline & & $B$ & Std. Error & & & \\
\hline \multirow[t]{3}{*}{1} & (Constant) & 134 &, 005 & & 26,365 &, 000 \\
\hline & NWCTO &,- 004 &, 002 &,- 408 & $-1,677$ &, 112 \\
\hline & FATO & 001 &, 002 & 089 & 368 &, 718 \\
\hline
\end{tabular}

a. Dependent Variable: NPM 
Berdasarkan data di atas, maka pengaruh antara modal kerja dan Aktiva tetap terhadap kemampulabaan pada PT. Kalbe Farma Tbk dapat diketahui dalam persamaan regresi sebagai berikut :

$$
Y=0,134-0,004_{x 1}+0,001_{x 2} \text {-Error }
$$

Persamaan tersebut menunjukkan bahwa nilai konstanta (a) sebesar 0,134 yang berarti bahwa bila nilai Net Working Capital Turnover dan Fixed Asset turnover = 0 maka kemampulabaan akan berkurang sebesar 0,134. Sementara itu nilai konstanta Net Working Capital Turnover sebesar -0,004 mengandung arti bahwa jika Net Working Capital Turnover naik sebesar satu satuan dan variable lainnya dianggap konstan maka kemampulabaan akan turun sebesar -0,004. Nilai konstanta FATO diperoleh sebesar 0,001 artinya jika FATO naik sebesar satu satuan dan variable lainnya konstan maka kemampulabaan akan meningkat sebesar 0,001.

ANOVA $^{b}$

\begin{tabular}{|ll|l|l|l|l|l|}
\hline Model & $\begin{array}{l}\text { Sum of } \\
\text { Squares }\end{array}$ & df & Mean Square & F & Sig. \\
\hline 1 & $\begin{array}{l}\text { Regression } \\
\text { Residual }\end{array}$ &, 000 & 2 &, 000 & 1,454 &, $261^{\mathrm{a}}$ \\
& Total &, 001 & 17 &, 000 & & \\
& & 19 & & & \\
\hline
\end{tabular}

a. Predictors: (Constant), FATO, NWCTO

b. Dependent Variable: NPM

Uji F ( Anova ) atau Uji koefisien regresi secara bersama - sama digunakan untuk mengetahui apakah variable independen Net Working Capital Turnover dan Fixed Aset Turnover secara bersama - sama tidak berpanguruh signifikan terhadap kemampulabaan. Berdasarkan hasil perhitungan seperti yang nampak pada tabel 4.2.5.3 diatas menunjukan bahwa $f$ hitung $<\mathrm{f}$ tabel $(1,454<3591)$ dan tingkat signifikansi 0,261 > 0,05 maka dapat dijelaskan bahwa variabel independen Net Working Capital Turnover dan Fixed Asset Turnover secara bersama - sama tidak memiliki hubungan yang signifikan terhadap Kemampulabaan ( NPM ).

\section{KESIMPULAN DAN SARAN}

\section{Kesimpulan}

1.Berdasarkan hasil analisis dari pembahasan pada bab-bab sebelumnya, maka penulis dapat mengambil kesimpulan yaitu sebagai berikut:

a. Dalam penelitian ini menunjukan bahwa modal kerja ( NWCTO ) PT. Kimia Farma dan PT. Kalbe Farma Tbk dilihat dari pertumbuhan setiap triwulannya dapat disimpulkan bahwa pada triwulan ke 4 tahun 2010 modal kerja PT. Kimia farma memiliki tingkat tertinggi yaitu sebesar 4,75. Sedangkan dari hasil analisis PT. Kalbe Farma Tbk modal kerja tertinggi terjadi pada triwulan ke 4 tahun 2013 sebesar 3,29. Hal ini dapat disimpulkan bahwa modal kerja PT. Kimia Farma Tbk lebih baik dari PT. Kalbe farma Tbk karena semakin cepat perputaran modal kerja yang dihasilkan maka akan semakin bagus.

b. Dalam penelitian ini perputaran Aktiva tetap (FATO) pada PT. kimia Farma Tbk memiliki trend yang cenderung meningkat, FATO tertinggi pada triwulan ke 4 tahun 2013 yaitu sebesar 6,57 yang berarti perusahaan sudah cukup maksimal dalam menggunakan Aktiva tetapnya untuk menghasilkan penjualan. sedangkan FATO tertinggi pada PT. Kalbe Farma Tbk terjadi pada triwulan ke 4 tahun 2010 yaitu sebesar 5,13. Hal ini dapat disimpulkan bahwa perputaran Aktiva tetap (FATO) PT. Kimia Farma Tbk lebih baik dari PT. Kalbe farma Tbk. 
c. Dalam penelitian ini kemampulabaan ( NPM ) pada PT. kimia Farma Tbk memiliki trend yang fluktuasi setiap triwulannya. Dimana NPM tertinggi pada triwulan ke 4 tahun 2012 yaitu sebesar 5,51\%. Sedangkan NPM tertinggi pada PT. Kalbe Farma Tbk terjadi pada triwulan ke 3 tahun 2011 yaitu sebesar 14,20\%. Hal ini dapat disimpulkan bahwa kemampulabaan (NPM) PT. Kalbe farma Tbk lebih baik dari PT. Kimia farma Tbk. Karena NPM yang tinggi menunjukkan bahwa dari penjualan yang tinggi mampu memberikan laba yang tinggi pula bagi perusahaan.

2. Hasil analisis statistik pengelolaan modal kerja dan modal tetap terhadap kemampulabaan pada PT. Kimia farma Tbk dan PT. Kalbe Farma Tbk diantaranya sebagai berikut:

a. Hasil analisis yang pertama antara modal kerja menggunakan indikator Net Working Capital Turnover ( NWCTO ) terhadap kemampulabaan menggunakan indikator Net Profit Margin ( NPM ) Pada PT. Kimia Farma Tbk dapat disimpulkan bahwa secara parsial mempunyai pengaruh yang signifikan pada periode 20102014 terlihat pada nilai signifikansi sebesar 0,020 atau 2\% dikarenakan lebih kecil dari 0,05 atau $5 \%$. Hal tersebut disebabkan karena kenaikan dan penurunan modal kerja diikuti dengan kenaikan dan penurunan dari kemampulabaan.

Untuk Hasil analisis antara modal kerja menggunakan indikator Net Working Capital Turnover ( NWCTO ) terhadap kemampulabaan menggunakan indikator Net Profit Margin ( NPM ) Pada PT. Kalbe Farma Tbk dapat disimpulkan bahwa secara parsial tidak mempunyai pengaruh yang signifikan pada periode 2010-2014 terlihat pada nilai signifikansi sebesar 0,105 atau 10,5\% dikarenakan lebih besar dari 0,05 atau $5 \%$. Hal tersebut disebabkan karena kenaikan dan penurunan modal kerja diikuti dengan kenaikan dan penurunan dari kemampulabaan dan ada faktor-faktor lain yang tidak diteliti yang dapat berpengaruh signifikan terhadap kemampulabaan.

b. Hasil analisis yang kedua antara aktiva tetap menggunakan indikator Fixed Asset Turnover ( FATO ) terhadap kemampulabaan menggunakan indikator Net Profit Margin ( NPM ) Pada PT. kimia farma Tbk dapat disimpulkan bahwa secara parsial mempunyai pengaruh yang signifikan pada periode 2010-2014 terlihat pada nilai signifikansi sebesar 0,004 atau 0,4\% dikarenakan lebih kecil dari 0,05 atau 5\%. Hal tersebut disebabkan karena PT. Kimia Farma Tbk mampu menggunkan Aktiva tetap perusahaan secara efektif dan efisien.

Untuk Hasil analisis antara aktiva tetap menggunakan indikator Fixed Asset Turnover ( FATO ) terhadap kemampulabaan menggunakan indikator Net Profit Margin ( NPM ) Pada PT. Kalbe Farma Tbk dapat disimpulkan bahwa secara parsial tidak mempunyai pengaruh yang signifikan pada periode 2010-2014 terlihat pada nilai signifikansi sebesar 0,774 atau 77,4\% dikarenakan lebih besar dari 0,05 atau $5 \%$. Hal tersebut disebabkan karena PT. Kalbe Farma kenaikan dan penurunan Aktiva tetap diikuti dengan kenaikan dan penurunan dari kemampulabaan dan ada faktor-faktor lain yang tidak diteliti yang dapat berpengaruh signifikan terhadap kemampulabaan.

c. Hasil analisis yang ke tiga yang dilakukan pada PT Kimia Farma Tbk menunjukkan hasil bahwa pengelolaan modal kerja ( NWCTO ), Aktiva tetap ( FATO ) secara bersama-sama berpengaruh signifikan terhadap kemampulabaan ( NPM ). Hal ini dapat dilihat dari nilai $f$ hitung $>\mathrm{f}$ tabel $(6,056>3591)$ dan berdasarkan tingkat signifikansi $0,010<0,05$. Besarnya pengaruh modal kerja ( NWCTO ) dan aktiva tetap ( FATO ) terhadap kemampulabaan ( NPM ) cukup sedang yaitu 0.416 atau $41,6 \%$, sedangkan sisanya $58,4 \%(1-41,6 \%)$ di pengaruhi oleh variabel lain yang tidak diteliti.

Sedangkan hasil analisis yang dilakukan pada PT Kalbe Farma Tbk menunjukkan hasil bahwa pengelolaan modal kerja ( NWCTO ), aktiva tetap ( FATO ) secara bersama-sama tidak berpengaruh signifikan terhadap kemampulabaan ( NPM ). Hal ini dapat dilihat dari nilai $f$ hitung $<f$ tabel $(1,454<3591)$ dan tingkat signifikansi 0,261 >0,05. Besarnya pengaruh modal kerja ( NWCTO) dan Aktiva 
tetap ( FATO ) terhadap kemampulabaan ( NPM ) sangat rendah yaitu 0.146 atau $14,6 \%$, sedangkan sisanya $85,4 \%(1-14,6 \%)$ di pengaruhi oleh variabel lain yang tidak diteliti.

\section{Saran}

Berikut ini adalah saran dari penulis berkaitan dengan hasil penelitian ini adalah sebagai berikut:

1. Saran bagi kedua perusahaan :

a. Meningkatkan kemampuan pengelolaan modal kerja (NWCTO) secara efektif dan efisien dengan maksimal agar penjualan dapat meningkat secara signifikan.

b. Meningkatkan kemampuan pengelolaan aktiva tetap (FATO) secara efektif dan efisien guna meningkatkan hasil produksi dan penjualan.

c. Meningkatkan efisiensi kegiatan produksi dan penjualan agar dapat meningkatkan keuntungan sehingga kemampulabaan perusahaan akan meningkat secara signifikan.

\section{Saran bagi peneliti:}

Bagi peneliti yang akan melakukan penelitian dengan topik yang sama, sebaiknya peneliti selanjutnya menambah jumlah indikator untuk masing-masing variabel baik variabel pengelolaan aktiva maupun variabel kemampulabaan, selain itu juga disarankan untuk menambah jumlah data sehingga hasil penelitian diharapkan akan lebih mendekati kebenaran.

\section{DAFTAR PUSTAKA}

Brigham, E. F an Houston, 2010. Dasar - dasar Manajemen Keuangan, Edisi sepuluh. Alih Bahasa Ali Akbar Yulianto. Jilid I. Salemba Empat: Jakarta.

Drs. Jumingan, Se, Mm, Msi. Analisis Laporan Keuangan. 2008. Bumi Aksara: Jakarta.

Harahap, S. Syafri. 2007. Teori Akuntansi Edisi Revisi 10. PT Raja Grafindo Persada: Jakarta.

Husnan, Suad. 2004. Dasar - dasar Manajemen Keuangan. Edisi Keempat. UPP AMP YKPM: Yogyakarta.

Ikatan Akuntansi Indonesia. 2007. Standar Akuntansi Indonesia. Salemba Empat: Jakarta.

James C. Van Horneang Jhon M. Wachowicz,Jr. 2009. Prinsip - Prinsip Manajemen Keuangan Buku Satu. Edisi Ke Dua Belas. Alih Bahasa oleh Kasmir. Salemba: Jakarta.

Kamaludin, Dr. Dan Indriani, rini, Msi., Sem., Akt. 2014. Manajemen Keuangan. CV Mandar Maju: Bandung. 
Kasmir. 2008. Analisis Laporan keuangan. Rajawali Per: Jakarta.

Martono dan Harjito Agus, 2010. Manajemen Keuangan. Edisi ke delapan. Ekonisia: Yogyakrta.

Masruroh. 2008. Manajemen Keuangan 2. Edisi Modul 5. Universitas Mercu Buana: Jakarta.

Mulyana, M. and Puspitasari, R., 2014. Analisis Faktor-faktor Yang Membentuk Minat Berwirausaha Siswa SMK di Kota Bogor.

Mulyana, M. and Maulana, M., 2013. Pengaruh Pelayanan Terhadap Kepuasan Pelanggan dan Implikasinya Terhadap Citra Perusahaan. Jurnal IImiah Manajemen Kesatuan, $1(2)$.

Riyanto, Bambang. 2011. Dasar - dasar Pembelanjaan Perusahaan. Edisi Keempat. BPFE: Yogyakarta.

S, Munawir. 2007. Anilisis laporan Keuangan. Liberty: Yogyakarta.

Sawir, Agnes. 2007. Analisis Kinerja Keuangan dan Perencanaan Keuangan Perusahaan. PT Gramedia Pustaka Utama: Jakarta.

Skusen dan Stice. 2011. Akuntansi Keuangan 2. Edisi 16. Salemba empat: Jakarta.

Sugiri. 2009. Pengantar Akuntansi 2. Edisi 12. BPFE: Yogyakarta.

Sutrisno. Manajemen Keuangan: teori, konsep \& aplikasi. 2009. Ekonosia: Yogyakarta.

Weston, Fred, J dan Thomas, E Copeland. 2010. Manajemen Keuangan. Jilid 2. Binarupa Aksara Publisher: Jakarta.

Weygandt, Jerry J and Kieso. 2007. Accounting Principles. Edisi Ketujuh. Alih Bahasa Herman Wibowo. Penerbit Salemba Empat: Jakarta.

http://m.kompasiana.com/post/read/631625/1/sekilas-ekonomi-indonesia-2014.html

http://www.kajianpustaka.com/2012/10/profitabilitas-perusahaan.html

http://turunanilmu.blogspot.com/2010/12/fungsi-dan-tujuan-manajemen-keuangan.html

http://tataririaprilia.wordpress.com/2013/04/08/analisis-perekonomian-indonesia/

http://www.idx..co.id

www.kimiafarma.co.id

www.kalbefarma.co.id 